\title{
Mutually distinguishing microRNA signatures of breast, ovarian and endometrial cancers in vitro
}

\author{
MARC HIRSCHFELD ${ }^{1,2}$, ISABEL GE $^{1}$, GERTA RÜCKER $^{3}$, JULIA WALDSCHMIDT $^{1}$, SEBASTIAN MAYER $^{1,4}$ \\ MARKUS JÄGER ${ }^{1}$, MATTHIAS VOIGT ${ }^{5}$, BERND KAMMERER ${ }^{6}$, CLAUDIA NÖTHLING $^{1}$, KAI BERNER $^{1}$, \\ DANIELA WEISS $^{1}{ }^{,}$JASMIN ASBERGER $^{1}$ and THALIA ERBES ${ }^{1}$ \\ ${ }^{1}$ Department of Gynecology and Obstetrics, Faculty of Medicine and Medical Center, University of Freiburg, \\ D-79106 Freiburg; ${ }^{2}$ Institute of Veterinary Medicine, Georg-August-University Gottingen, D-37077 Gottingen; \\ ${ }^{3}$ Institute of Medical Biometry and Statistics, Faculty of Medicine and Medical Center, University of Freiburg, \\ D-79104 Freiburg; ${ }^{4}$ Department of Gynecology and Obstetrics, Hospital Memmingen, D-87700 Memmingen; \\ ${ }^{5}$ Praxis of Plastic and Aesthetic Surgery and Evangelian Deaconry Hospital, D-79110 Freiburg; \\ ${ }^{6}$ Center for Biological Systems Analysis, University of Freiburg, D-79104 Freiburg, Germany
}

Received November 21, 2019; Accepted July 6, 2020

DOI: $10.3892 / \mathrm{mmr} .2020 .11466$

\begin{abstract}
Early diagnosis and therapy in the first stages of a malignant disease is the most crucial factor for successful cancer treatment and recovery. Currently, there is a high demand for novel diagnostic tools that indicate neoplasms in the first or pre-malignant stages. MicroRNAs (miRNA or miR) are small non-coding RNAs that may act as oncogenes and downregulate tumor-suppressor genes. The detection and mutual discrimination of the three common female malignant neoplasia types breast (BC), ovarian (OC) and endometrial cancer (EC) could be enabled by identification of tumor entity-specific miRNA expression differences. In the present study, the relative expression levels of $25 \mathrm{BC}, \mathrm{EC}$ and OC-related miRNAs were assessed by reverse transcription-quantitative PCR and determined using the $2^{-\Delta \Delta \mathrm{Cq}}$ method for normalization against the mean of four housekeeping genes. Expression levels of all miRNAs were analyzed by regression against cell line as a factor. An expression level-based discrimination between BC and OC cell types was obtained for a subgroup of ten different miRNA types. miR-30 family genes, as well as three other miRNAs, were found to be uniformly upregulated in OC cells compared with BC cells. BC and EC cells could be distinguished by the expression profiles of six specific miRNAs. In
\end{abstract}

Correspondence to: Dr Thalia Erbes, Department of Gynecology and Obstetrics, Faculty of Medicine and Medical Center, University of Freiburg, 55 Hugstetter Street, D-79106 Freiburg, Germany

E-mail: thalia.erbes@uniklinik-freiburg.de

Abbreviations: $\mathrm{BC}$, breast cancer; EC, endometrial cancer; miRNA/miR, microRNA; OC, ovarian cancer

Key words: microRNA, breast cancer, endometrial cancer, ovarian cancer, diagnosis addition, four miRNAs were differentially expressed between EC and OC cells. In conclusion, miRNAs were identified as a potential novel tool to detect and mutually discriminate between $\mathrm{BC}, \mathrm{OC}$ and EC. Based on a subset of 25 clinically relevant human miRNA types, the present study could significantly discriminate between these three female cancer types by means of their expression levels. For further verification and validation of miRNA-based biomarker expression signatures that enable valuable tumor detection and characterization in routine screening or potential therapy monitoring, additional and extended in vitro analyses, followed by translational studies utilizing patients' tissue and liquid biopsy materials, are required.

\section{Introduction}

The success rate in the clinical treatment of neoplastic disease remains highly associated with early detection of pre-malignant or first stages of malignant tissues. To date, only few highly specific and sensitive biomarkers are routinely used in the clinic for early-stage cancer screening or diagnostics.

Due to mammography screening, which was first introduced in 2005 in Germany, breast cancer (BC) has been identified at earlier stages, when treatment options are most promising and prognosis is most favorable (1). For endometrial cancer (EC) and ovarian cancer (OC), no standardized screening has yet been established. Postmenopausal bleeding serves as an early indicator of EC $(2,3)$ European studies have shown that the 5-year survival rate of endometrial adenocarcinoma is $>90 \%$ when detected at stage I compared with a survival rate of $\sim 50 \%$ for advanced stages (II, III, IV) $(3,4)$. $\mathrm{OC}$ remains one of the most challenging types of cancer to detect and treat. In most cases, tumor progression and metastasis are unnoticed until the advanced stages (5). According to the Surveillance, Epidemiology and End Results Program (National Cancer Institute, USA) database, the 5-year survival rate for localized disease is $>90 \%$ in the USA population (6), 
however only $20 \%$ of ovarian cancer cases are detected at such an early stage in the USA $(5,7)$.

One possible approach in the identification of novel potential biomarker candidates is based on expression profiling of different states, for example comparing malignant and healthy control expression profiles (7). In a stepwise filtering process, the discovery, qualification, verification, potential candidate prioritization and subsequent validation in adequate cohort sizes demonstrate the applicability of a biomarker for clinical practice implementation (7). Among a multitude of potential biomarker types, in previous years one group of nucleic acids has gained significant attention due to their diverse regulatory functions (8).

MicroRNAs (miRNAs or miRs) are small non-coding RNA molecules of 22 nucleotides in length, which are involved in the post-transcriptional regulation of gene expression, predominately via gene silencing. By binding to various mRNA targets, upregulation of miRNA leads to reduced translation of mRNA or degradation of its transcript (9). In cancer, dysregulated miRNA expression plays an important role by upregulating oncogenes and downregulating tumor-suppressor genes, thus modulating cell proliferation, differentiation, apoptosis and stress response (10). The regulatory influence of miRNAs in breast and gynecological cancer biology has been demonstrated in a growing number of studies $(8,11-17)$. The selection of miRNAs in the present study was based on an extensive literature search, with the major criterion being expression changes in the tumor types of BC, EC and OC (Table I), in combination with a proven detectability of all analyzed miRNA types in in vitro models as well as in human urine samples (18-20).

miRNA-21 (miR-21) is one of the most common miRNAs in epithelial cancer, and it generally promotes anti-apoptotic effects in various malignant tissues and cell lines, including $\mathrm{BC}, \mathrm{OC}$ and EC, by downregulating tumor suppressors, such as phosphatase and tensin homolog $(21,22)$ and programmed cell death protein 4 (23). In patients with BC, overexpression of miR-21 in the tumor is associated with advanced tumor stage, lymph node metastasis and poor survival (24). Whereas, in $\mathrm{OC}$ cell lines, miR-21 promotes pathways that enhance chemoresistance (25).

In contrast to miR-21, members of the miRNA family let-7 have most commonly been reported as tumor suppressors by downregulating Harvey rat sarcoma viral oncogene homolog and high-mobility group AT-hook 2 (26). However, studies have reported inconsistent results regarding the individual member let-7b. While some studies reported that high levels of let-7b in serum and plasma was associated with a favorable prognosis in cancer $(27,28)$, a previous meta-analysis demonstrated reduced survival rates in high-grade serous OC with high tissue expression of let-7b (29). The tumor suppressing miRNA family miR-30 has been reported to exhibit pro-apoptotic effects by silencing ubiquitin-conjugating enzyme 9 and integrin $\beta 3$ (30). In BC, miR-30a inhibits cell migration and invasion (31), whereas expression of miR-30c in tissues is associated with benefits during endocrine treatment (32) and regulatory effects in chemotherapy resistance processes (33). Notably, high expression levels of miR-30c and miR-30e have been observed in OC compared with normal tissue; however, both miRNAs are associated with an improved prognosis (34-36).
A more homogenous profiling has been observed for miR-125b and miR-100. miR-125b and miR-100 mediate the Erb-B2 receptor tyrosine kinase 2 and mechanistic target of rapamycin pathways, respectively, and downregulation of both miRNAs has been reported in BC, OC and EC tissue and cell lines (37-41). The previously described functional implications of the investigated miRNAs in BC, EC and OC tumor biology are summarized in Table I.

Due to recent investigations on miRNAs that are commonly conducted based on different study designs and environments, the comparison and interpretation of results between multiple cancer types have become increasingly challenging. The goal of the present study was to evaluate differences of miRNA profiling in three of the most common female cancer types: BC, OC and EC. Instead of solely focusing on individual miRNA types or families, the present study aimed to investigate the expression patterns of miRNAs that have great potential to serve as promising diagnostic tools in the distinction of different tumor types. Based on three cell types for each type of malignancy, BC, OC and EC, the detected differences in quantitative expression levels of a set of 25 miRNAs revealed diagnostic biomarker features clustered in tumor-entity-specific 'miRNA signatures'. To this end, the in vitro models used were selected to represent a range of common subtypes/properties of the respective carcinomas. The data obtained in this first phase biomarker identification study serve as a basis to prioritize distinct miRNAs with diagnostic significance that will be investigated in future studies.

\section{Materials and methods}

Cell culture conditions and treatments. The BC cell lines BT-20 (cat. no. 300130; CLS Cell Lines Service GmbH), BT-474 (cat. no. 00131; CLS Cell Lines Service GmbH) and SK-BR-3 (cat. no. 300333; CLS Cell Lines Service GmbH), the EC cell lines Ishikawa (cat. no. 99040201; Sigma-Aldrich; Merck KGaA), EFE-184 (cat. no. ACC 230; Leibniz Institute DSMZ-German Collection of Microorganisms and Cell Cultures $\mathrm{GmbH}$ ) and AN3CA (cat. no. 300119; CLS Cell Lines Service GmbH), and the OC cell lines SK-OV-3 (cat. no. 300342; CLS Cell Lines Service GmbH), EFO-27 (cat. no. ACC 191; Leibniz Institute DSMZ-German Collection of Microorganisms and Cell Cultures GmbH) and OAW-42 (cat. no. 300304; CLS Cell Lines Service $\mathrm{GmbH}$ ) were incubated in a humidified atmosphere at $37^{\circ} \mathrm{C}$ and $5 \% \mathrm{CO}_{2}$. Ishikawa cells were cultured in RPMI-1640 (Gibco; Thermo Fisher Scientific, Inc.) supplemented with $10 \%$ newborn calf serum (Gibco; Thermo Fisher Scientific, Inc.), 1\% HEPES buffer (Gibco; Thermo Fisher Scientific, Inc.) and $100 \mathrm{U} / \mathrm{ml}$ Penicillin/Streptomycin (Sigma-Aldrich; Merck KGaA). The BT-20, SK-BR-2, EFE-184, AN3CA, SK-OV-3 and EFO-28 cells were cultured in DMEM/F12 (cat. no. 31331-028; Thermo Fisher Scientific, Inc.) supplemented with $10 \%$ newborn calf serum, $1 \%$ HEPES buffer and $100 \mathrm{U} / \mathrm{ml}$ Penicillin/Streptomycin. The BT-47 and OAW-42 cells were cultured in DMEM/F12 supplemented with $2.5 \%$ insulin (Insuman rapid ${ }^{\circledR}$; Sanofi S.A.).

miRNA isolation. miRNA from cultured cells was isolated using the innuPREP Micro RNA kit (Analytik Jena US LLC), according to the manufacturer's instructions. Isolated RNA 


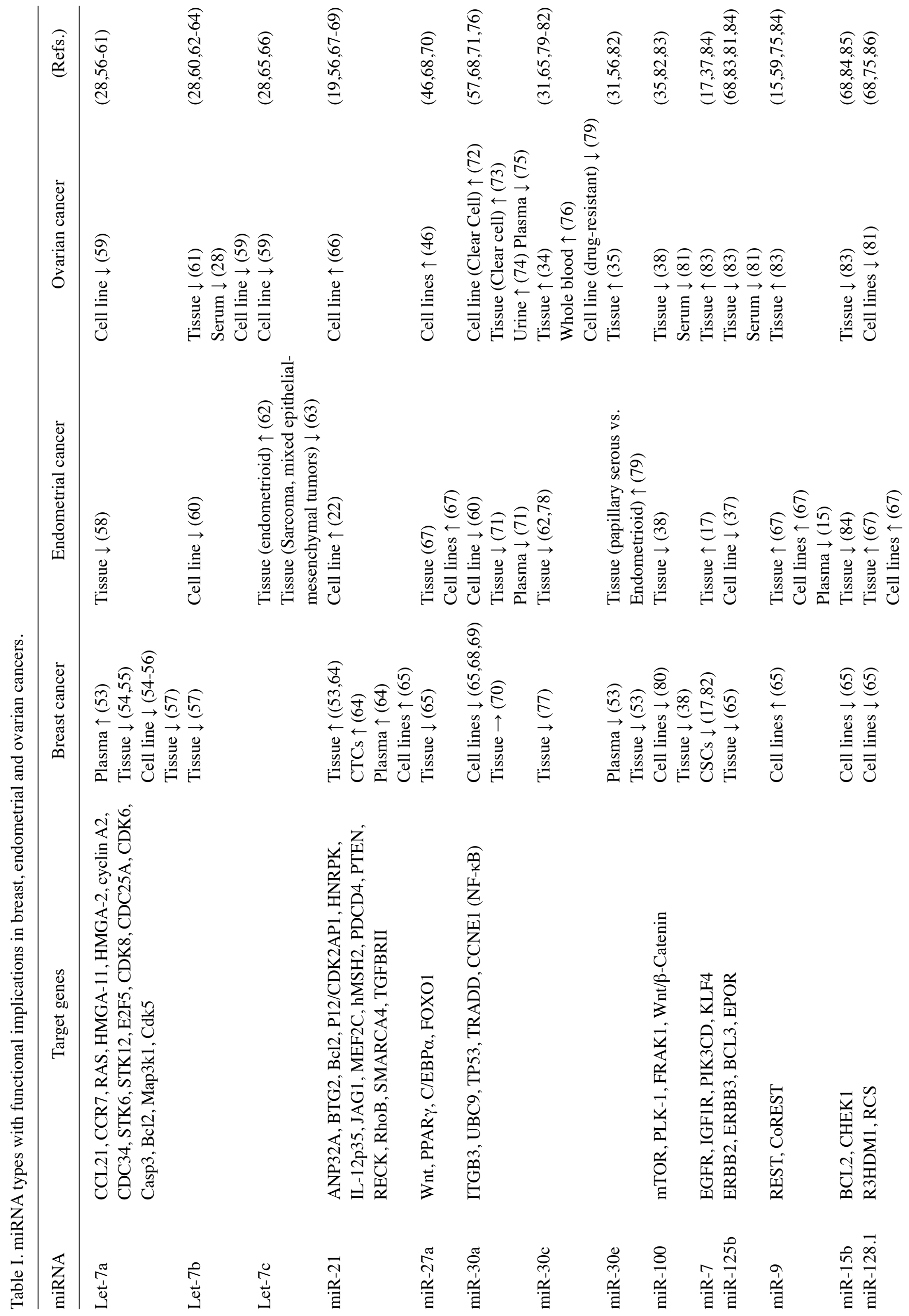




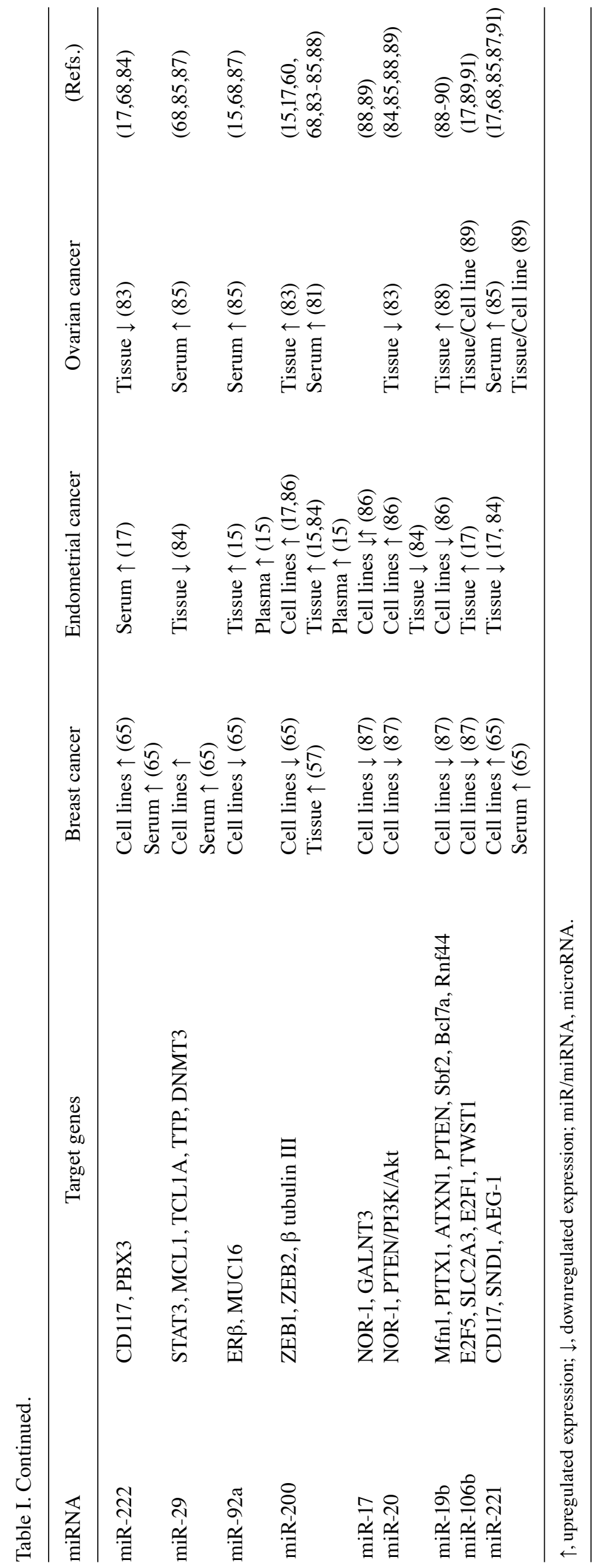


was quantitatively determined using the NanoDrop ND1000 (VWR International $\mathrm{GmbH}$ ). RNA samples were stored at $-20^{\circ} \mathrm{C}$ until further processing.

Reverse transcription-quantitative PCR (RT-qPCR). Total RNA was isolated using GeneMATRIX Universal RNA/miRNA Purification kit (cat. no. E3599; EURx ${ }^{\circledR}$; Roboklon $\mathrm{GmbH}$ ) according to manufacturer's protocol. A total of $1 \mu \mathrm{g}$ isolated RNA per sample was used for RT. The RT reaction mix contained $5 \mu \mathrm{l}$ RT-buffer (5X), $1 \mu 12.5 \mu \mathrm{M}$ poly A adapter primer (Apara Bioscience $\mathrm{GmbH}$ ), $0.5 \mu 15 \mathrm{mM}$ dNTPs (Jena Bioscience), $0.25 \mu \mathrm{l}$ Maxima reverse transcriptase (Thermo Fisher Scientific, Inc.), $0.25 \mu 1$ SUPERase In RNase inhibitor (Thermo Fisher Scientific, Inc.), $0.5 \mu 110 \mathrm{mM}$ ATP (New England Biolabs, Inc.), $0.25 \mu l$ poly A polymerase, and $1 \mu \mathrm{g}$ RNA sample. The reaction was performed on a thermal cycler (Eppendorf) at $37^{\circ} \mathrm{C}$ for $60 \mathrm{~min}$ and stopped at $85^{\circ} \mathrm{C}$ for $10 \mathrm{~min}$. Processed cDNA was stored at $4^{\circ} \mathrm{C}$.

The relative expression levels of specific miRNAs were assessed by qPCR using the SYBR-Green assay in a duplicate analysis. A total of $1 \mu \mathrm{l}$ cDNA per sample with a concentration of $5 \mathrm{ng} / \mu \mathrm{l}$ was mixed with $9 \mu \mathrm{l}$ Master Mix, containing $1 \mu \mathrm{l}$ buffer (10X), $0.5 \mu 15 \mathrm{mM}$ dNTPs (Jena Bioscience $\mathrm{GmbH}$ ), $0.5 \mu 15 \mu \mathrm{M}$ primer (Apara), $0.5 \mu 1 \mathrm{SYBR}-\mathrm{Green}$ (Roche Diagnostics), $0.05 \mu 1$ HotStart Taq (Jena Bioscience GmbH) and $6.45 \mu \mathrm{l}$ nuclease-free water (Analytik Jena US LLC). The primer pairs consisted of a universal reverse primer (30-32) and a specific miRNA sense primer. The qPCR was performed on a LightCycler ${ }^{\circledR} 480$ instrument (Roche Diagnostics) at $95^{\circ} \mathrm{C}$ for $5 \mathrm{~min}$, followed by 40 cycles at $95^{\circ} \mathrm{C}$ for $5 \mathrm{sec}, 62^{\circ} \mathrm{C}$ for $15 \mathrm{sec}$ and $72^{\circ} \mathrm{C}$ for $10 \mathrm{sec}$. Data were analyzed with the LightCycler ${ }^{\circledR}$ 480 software (Roche Molecular Systems, Inc.; Version 1.5.1). The relative expression of each miRNA was determined using the $2^{-\Delta \Delta \mathrm{Cq}}$ method $(42,43)$ based on the housekeeping genes small nucleolar RNA, C/D box 48 (RNU48), miR-26b, miR-16 and miR-103, with the 'BestKeeper' software tool (Version 1) (43). The specific primer sequences are listed in Table II.

Statistical analysis. The expression levels of all BC, EC and OC-associated miRNAs were determined as mean $\Delta C_{q}$ values of the miRNA normalized against the geometric mean of the four housekeeping genes RNU48, miR-16, miR-26b and miR-103. The expression levels of all miRNA types were separately analyzed using a linear model with cell line as the independent variable. The regression coefficients with $95 \%$ confidence intervals were tabulated. This led to color coded heatmaps in which red colors indicate strong deviations in the positive direction and blue colors indicate strong deviations in the negative direction from the expression level in the cell line that served as a reference (AN3CA, BT-474 and BT-20). Dark colors correspond to a $\mathrm{P}<0.00005$, and light colors correspond to a $\mathrm{P}<0.00025$. All other comparisons are presented in gray.

\section{Results}

miRNA expression profiles of the cell lines. In the present study, the expression levels of $25 \mathrm{BC}, \mathrm{EC}$ and $\mathrm{OC}$-associated miRNAs (let-7a, let-7b, let-7d, miR-7, -9, -15b, -17, -19b, -20a, $-20 \mathrm{~b},-21,-27 \mathrm{a},-29 \mathrm{a},-30 \mathrm{a},-30 \mathrm{c},-30 \mathrm{e},-92 \mathrm{a},-100,-106 \mathrm{~b},-125 \mathrm{~b}$,
Table II. Primer sequences.

\begin{tabular}{ll}
\hline Primer & \multicolumn{1}{c}{ Sequence $\left(5^{\prime} \rightarrow 3^{\prime}\right)$} \\
\hline miRNA poly & GAAGACTCAGTTGCACTCTACCAAT \\
A RT & TAAGACGAACAGAGCCATACTTTTT \\
Universal & TTTTTTNN \\
antisense & \\
miR-16-5p & GGCTAGCAGCACACGTAAATATTG \\
miR-26b-5p & GGCGTTCAAGTAATTCAGGATAG \\
RNU48 & TGTGTCGCTGATGCCATC \\
miR-103-5p & CGGAGCAGCATTGTACAGG \\
let-7a-5p & CGGTGAGGTAGTAGGTTGTATAGTT \\
let-7b-5p & CGTGAGGTAGTAGGTTGTGTG \\
let-7d-5p & CGGAGAGGTAGTAGGTTGCATA \\
miR-7-5p & CGGTGGAAGACTAGTGATTTTGT \\
miR-9-5p & CGGTCTTTGGTTATCTAGCTGTAT \\
miR-15b-5p & GCTAGCAGCACATCATGGTTTA \\
miR-17-5p & GCAAAGTGCTTACAGTGCAG \\
miR-19b-3p & GTGTGCAAATCCATGCAAAACT \\
miR-20a-5p & CGGTAAAGTGCTTATAGTGCAGGTA \\
miR-20b-5p & CAAAGTGCTCATAGTGCAGGTA \\
miR-21-5p & GGCTAGCTTATCAGACTGATGTT \\
miR-27a-3p & GGCTTCACAGTGGCTAAGTT \\
miR-29a-3p & GTAGCACCATCTGAAATCGGTT \\
miR-30a-5p & GTGTAAACATCCTCGACTGGAA \\
miR-30c-5p & GCTGTAAACATCCTACACTCTCA \\
miR-30e-5p & GGTGTAAACATCCTTGACTGGAA \\
miR-92a-3p & GTATTGCACTTGTCCCGGC \\
miR-100-5p & GAACCCGTAGATCCGAACTT \\
miR-106b-5p & GCTAAAGTGCTGACAGTGCA \\
miR-125b-5p & GCTCCCTGAGACCCTAACTT \\
miR-128-1-3p & GTCACAGTGAACCGGTCTCTT \\
miR-200b-3p & CGGTAATACTGCCTGGTAATGAT \\
miR-200c-3p & CGTAATACTGCCGGGTAATGAT \\
miR-221-3p & GCTACATTGTCTGCTGGGTT \\
miR-222-3p & CGAGCTACATCTGGCTACT \\
\hline
\end{tabular}

miR, microRNA.

$-128.1,-200 b,-200 c,-221,-222)$ were quantified in three BC, $\mathrm{EC}$ and $\mathrm{OC}$ cell lines. The characteristics of each cell line are presented in Table III.

The statistical analyses demonstrated that comparing the three different cell types (AN3CA, BT-474 and BT-20) revealed a range of moderately to highly differentially expressed miRNAs, which exhibited either marked upregulation or downregulation. By clustering miRNAs with respect to their differential expression characteristics, subgroups of miRNAs featuring potential biomarkers to discriminate between $\mathrm{BC}, \mathrm{OC}$ and EC cells could be created. The expression data clearly revealed a BC-associated miRNA subpanel with significantly distinct expression levels compared with the gynecological tumor types EC and OC (miRs: let-7b, -21 , $-27 \mathrm{a},-30 \mathrm{a},-30 \mathrm{c},-30 \mathrm{e})$. Consecutively, miRNA clusters with 


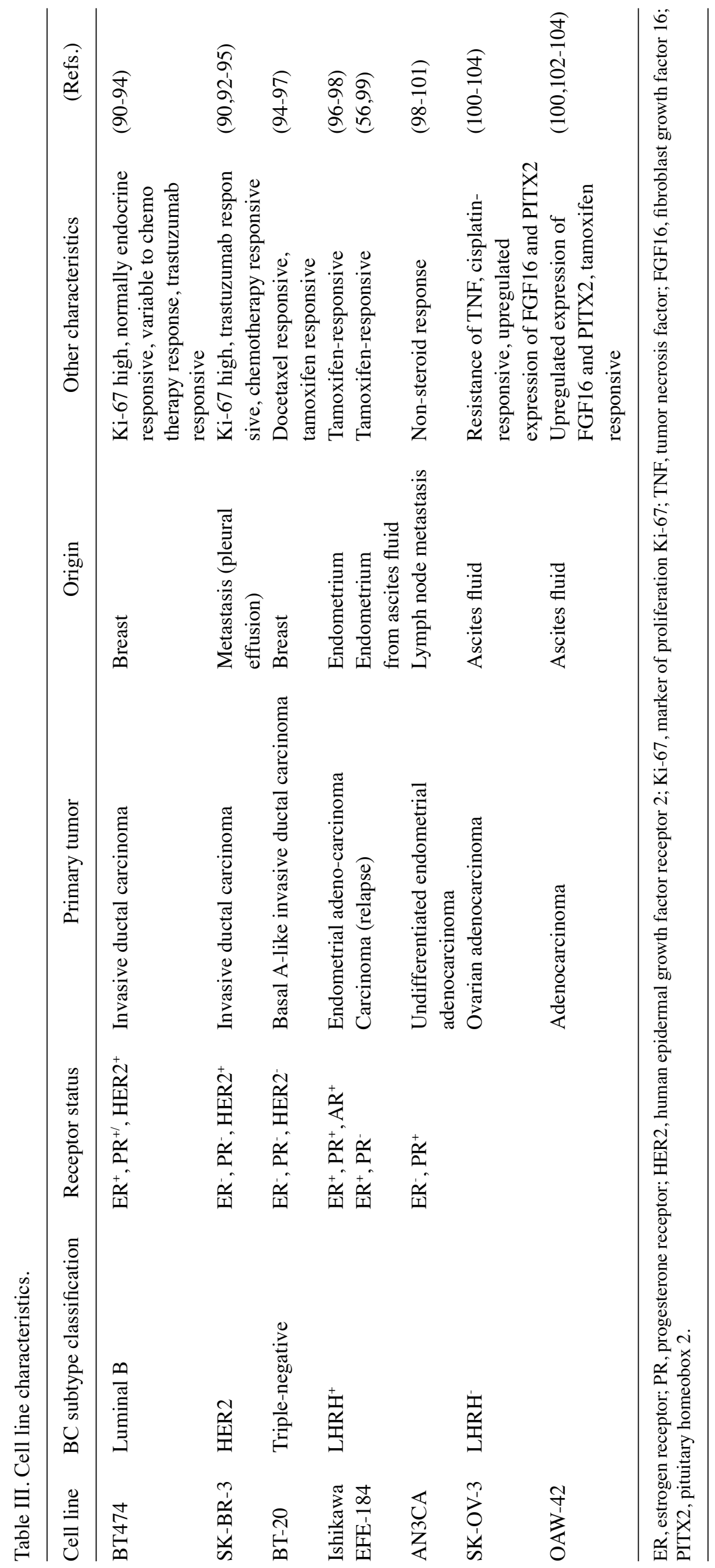




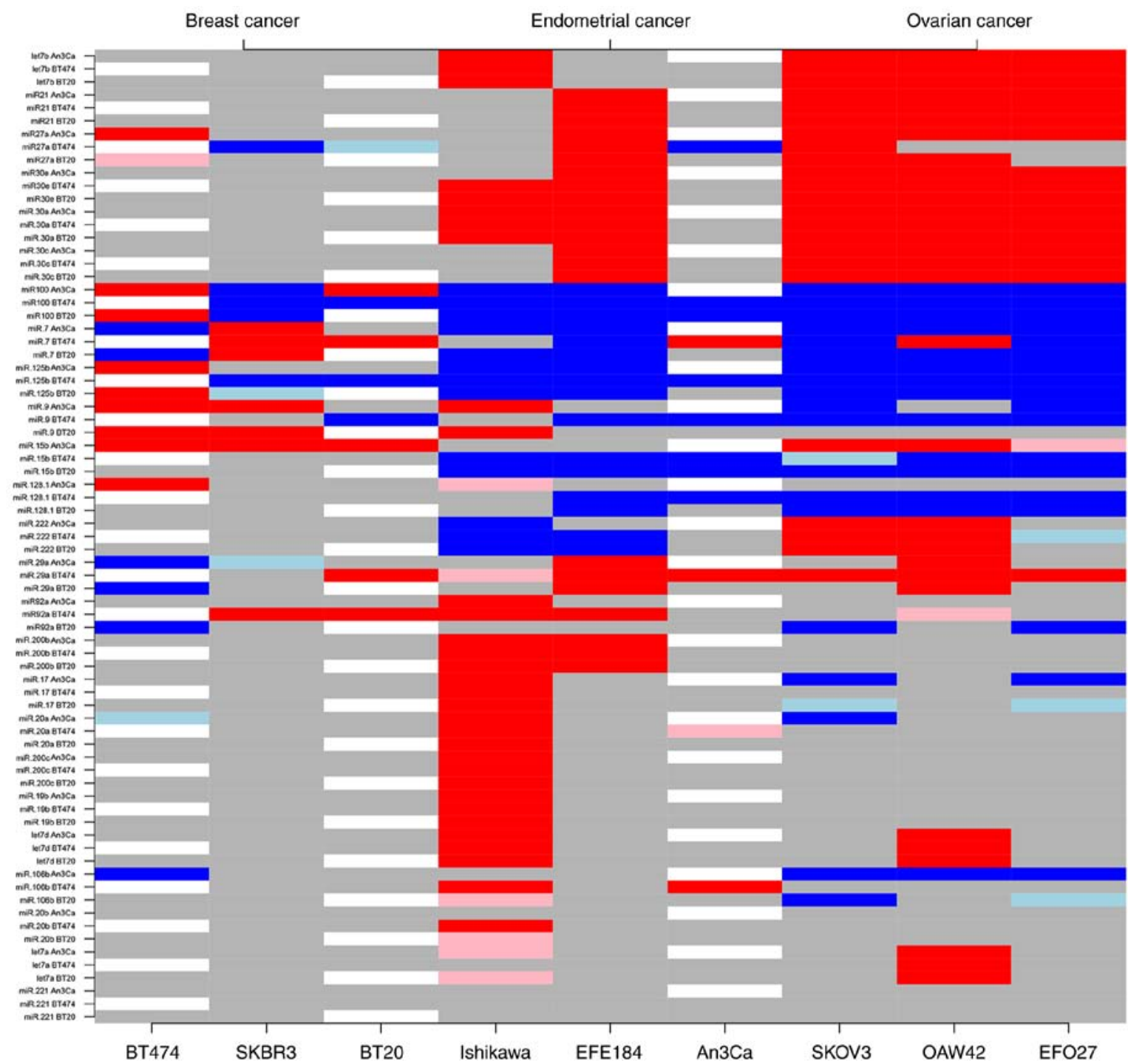

Figure 1. Mutual expression differences of distinct miRNA types in breast, endomometrial and ovarian cancer cell lines. The colors indicate either miRNA overexpression on a significant (light red, $\mathrm{P}<0.00025)$ or highly significant (red, $\mathrm{P}<0.00005)$ level, or decreased miRNA expression levels on a significant (light blue, $\mathrm{P}<0.00025$ ) or highly significant (blue, $\mathrm{P}<0.00005$ ) level. Gray indicates insignificant expression differences, and white indicates the reference parameter. miRNA, microRNA.

statistical relevance were defined to allow for discrimination between the three tumor entities in a one-versus-one approach (Fig. 1 and Tables SI-SIII).

miRNAs discriminating BC from OC cells. Expression analyses could determine a subgroup of ten different miRNAs (miRs: let-7b, -21, 30a, -30c, -30e, -27a, -222, -29a, -128.1, -9) that facilitated an expression level-based discrimination between the $\mathrm{BC}$ and $\mathrm{OC}$ cell types. The notable types included let-7b, miR-21 and the miR-30 family genes, which were uniformly upregulated in $\mathrm{OC}$ cells compared with $\mathrm{BC}$ cells. For example, compared with AN3CA cells, miR-let-7b was upregulated by a mean value of 5.08 (95\% confidence interval, 4.51, 5.65; $\mathrm{P}<0.001)$ in $\mathrm{SK}-\mathrm{OV}-3,8.37(7.80,8.94 ; \mathrm{P}<0.001)$ in OAW-42 cells, and $2.53(1.96,3.10 ; \mathrm{P}<0.001)$ in EFO-27 OC cells (Table SI). In contrast, regression analyses demonstrated no significant difference of miR-let-7b in all investigated BC cell lines (Fig. 2 and Table SII). The expression levels of miR-30a, miR-30c and miR-30e were also increased in all three investigated OC cell lines. Specifically, compared with AN3CA cells, the miR-30a was significantly increased by a mean value of $0.22(0.21,0.23 ; \mathrm{P}<0.001)$ in SK-OV-3, $0.12(0.10$, $0.13 ; \mathrm{P}<0.001)$ in $\mathrm{OAW}-42$ cells, and $0.43(0.42,0.44 ; \mathrm{P}<0.001)$ in EFO-27 OC cells. The expression levels of miR-30c and miR-30e were also upregulated by a mean value of $0.21(0.17$, $0.25 ; \mathrm{P}<0.001)$ and $0.07(0.06,0.08 ; \mathrm{P}<0.001)$ in SK-OV-3 cells, $0.12(0.08,0.16 ; \mathrm{P}<0.001)$ and $0.03(0.02,0.04 ; \mathrm{P}<0.001)$ in OAW-42 cells, and $0.50(0.46,0.55 ; \mathrm{P}<0.001)$ and $0.16(0.15$, 0.17; $\mathrm{P}<0.001$ ) in EFO-27 OC cells (Table SI). No significant differences were identified among all BC cell lines (Table SII). miR-27 and miR-29a exhibited a moderate downregulation in $\mathrm{BC}$ cells, with few inconsistent results depending on the cell line comparison (AN3CA or BT-474). By contrast, miR-9 and miR-128.1 exhibited a general moderate downregulation in OC cells compared with BC cells (Fig. 2 and Tables SI and SII).

miRNAs discriminating $B C$ from EC cells. Among the 25 miRNAs evaluated in the present study, six exhibited 


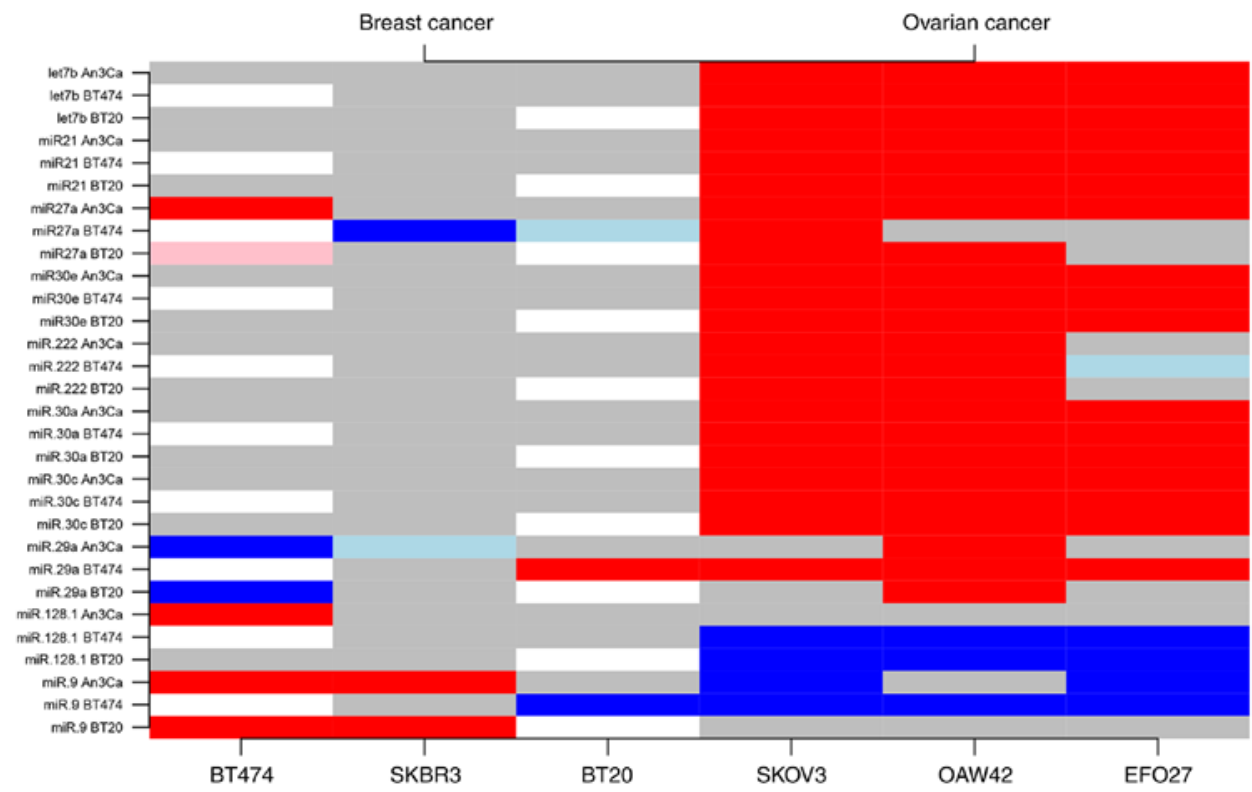

Figure 2. Mutual expression differences of miRNA types in the comparison of breast vs. ovarian cancer cell lines. The colors indicate either miRNA overexpression on a significant (light red, $\mathrm{P}<0.00025$ ) or highly significant (red, $\mathrm{P}<0.00005$ ) level, or decreased miRNA expression levels on a significant (light blue, $\mathrm{P}<0.00025$ ) or highly significant (blue, $\mathrm{P}<0.00005$ ) level. Gray indicates insignificant expression differences, and white indicates the reference parameter. miRNA, microRNA.

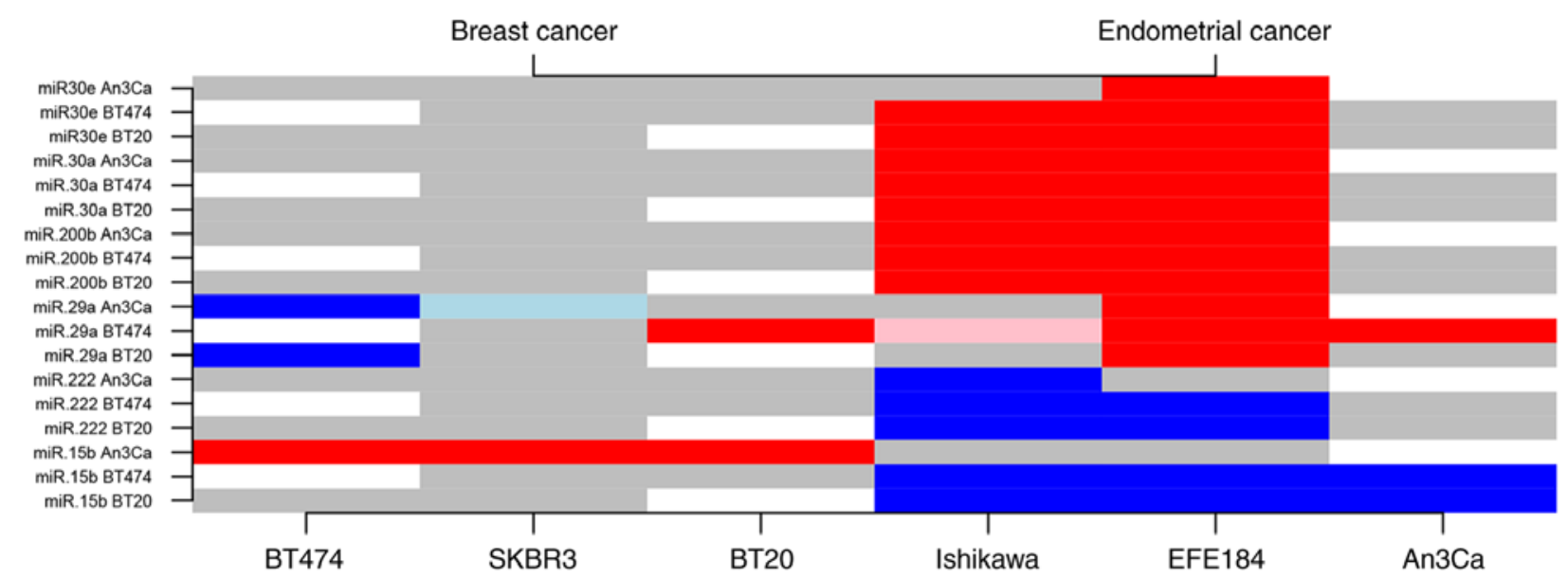

Figure 3. Mutual expression differences of miRNA types in the comparison of breast vs. endometrial cancer cell lines. The colors indicate either miRNA overexpression on a significant (light red, $\mathrm{P}<0.00025$ ) or highly significant (red, $\mathrm{P}<0.00005)$ level, or decreased miRNA expression levels on a significant (light blue, $\mathrm{P}<0.00025$ ) or highly significant (blue, $\mathrm{P}<0.00005)$ level. Gray indicates insignificant expression differences, and white indicates the reference parameter. miRNA, microRNA.

distinguishing characteristics in regard to $\mathrm{BC}$ compared with EC cell expression profiles (miRs: $-30 \mathrm{a},-30 \mathrm{e},-29 \mathrm{a},-15 \mathrm{~b},-200 \mathrm{~b}$, -222). While miR-29a, $-30 a,-30 c$ and $-200 b$ were found to be upregulated in EC cells, miR-15b and miR-222 demonstrated downregulated expression levels in comparison to $\mathrm{BC}$ cells. For example, miR-200b was upregulated by a mean value of $5.43(5.27,5.58 ; \mathrm{P}<0.001)$ in Ishikawa cells and by $0.97(0.81$, 1.12; $\mathrm{P}<0.001)$ in EFE-184 EM cells. Notably, AN3CA cells did not fully comply to the EC-specific expression level trends, which may be explained by cell-specific molecular characteristics (Fig. 3 and Tables SII and SIII).

miRNAs discriminating OC from EC cells. A total of four miRNAs (miR-92a, -106b, -200b, -222) with altered expression levels that may serve a role in the determination of endometrial compared with ovarian malignancies were identified based on this in vitro approach. Upregulated expression levels of miR-92a, -106b and -200b in EC cell types, as well as an upregulation of miR-222 in OC cells may help to mutually distinguish between these tumor types. Compared with AN3CA cells, miR-222 expression was increased by a mean value of $0.66(0.52,0.80 ; \mathrm{P}<0.001)$ in $\mathrm{SK}-\mathrm{OV}-3$ cells and by $0.85(0.71,0.99 ; \mathrm{P}<0.001)$ in $\mathrm{OAW}-42$ OC cells. By contrast, a downregulation was identified in two EC cell lines by a mean value of $0.48(-0.62,-0.34 ; \mathrm{P}<0.001)$ in Ishikawa cells and by $0.18(-0.32,-0.04 ; \mathrm{P}=0.018)$ in EFE-184 EM cells. However, individual cell line-specific differences need to be taken into account in the assessment of tumor type determination of a 


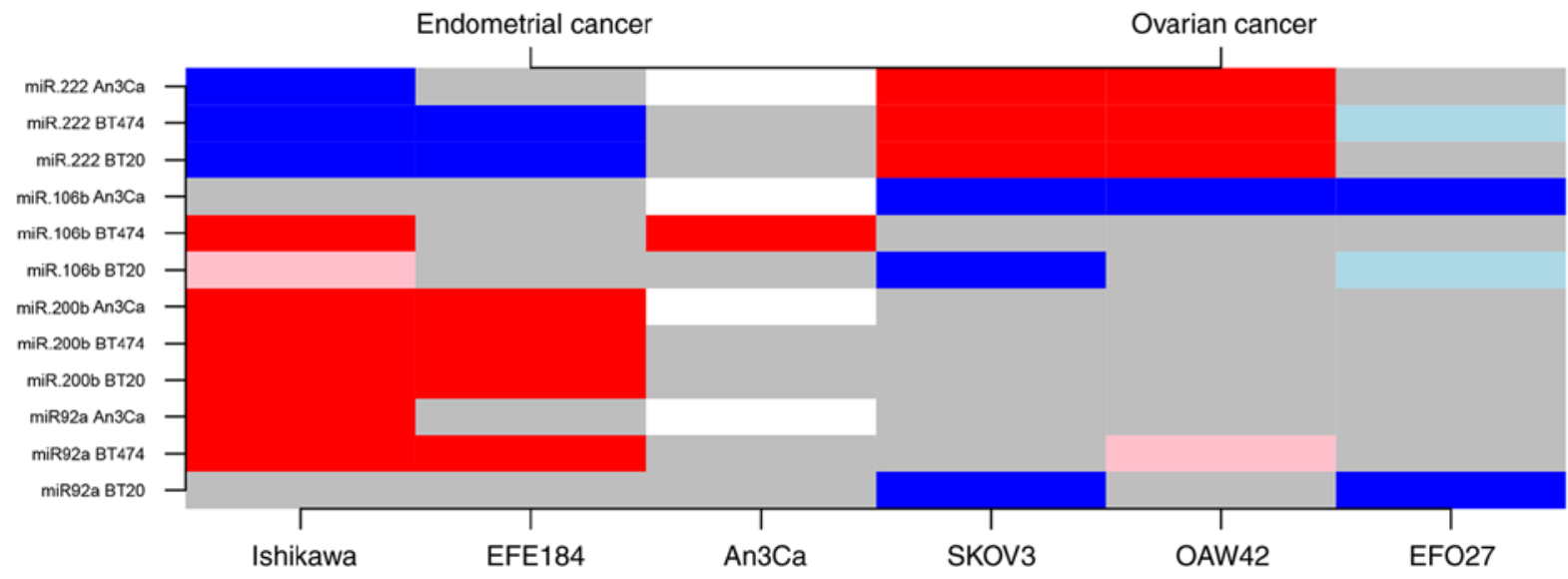

Figure 4. Mutual expression differences of miRNA types in the comparison of endometrial vs. ovarian cancer cell lines. The colors indicate either miRNA overexpression on a significant (light red, $\mathrm{P}<0.00025)$ or highly significant (red, $\mathrm{P}<0.00005)$ level, or decreased miRNA expression levels on a significant $($ light blue, $\mathrm{P}<0.00025$ ) or highly significant (blue, $\mathrm{P}<0.00005$ ) level. Gray indicates insignificant expression differences, and white indicates the reference parameter. miRNA, microRNA

potential miRNA subpanel with diagnostic power in this regard (Fig. 4 and Tables SI and SIII).

\section{Discussion}

The search for clinically applicable biomarkers necessitates a stringent multi-step selection process to singularize, evaluate and validate the usability of a potential biomolecule, or even grouped biomolecule expression profiles or signatures for clear diagnostic purposes. The present study focused on one possible initial step in the determination of potential novel biomarkers that help to detect and distinguish healthy women from patients with malignant disease of the breast, endometrium or ovaries. Based on an in vitro model approach, the proof of principle was accomplished to corroborate the initial hypothesis of discriminating diagnostic features of miRNA signatures in the diagnosis of breast and gynecological malignancies. In general, the detected intracellular miRNA expression levels can be transferred to the extracellular setting of secreted miRNAs, as shown in a previous study (20). Therefore, the experimental design of the present study was targeted on the identification of miRNA signatures, based on tumor-specific expression differences, that enable the mutual discrimination of the three common female cancer types BC, OC and EC. Since miRNAs are robust and easily accessible biomolecules that can be quantified in a wide range of biomaterials, including tissue and liquid biopsies, they meet important requirements for modern and applicable diagnostic biomarkers (44). Thousands of different human miRNAs have been described, of which a clinically relevant subset of 25 different miRNAs with potential impacts in $\mathrm{BC}, \mathrm{EC}$ and/or OC was pre-selected for the present analytical in vitro approach. Although certain differences in cell line-based and in vivo settings need to be kept in consideration, the current study is intended to provide initial findings that guide further investigations in a promising direction.

Global expression profile analyses in the present study resulted in the identification of cancer type-specific miRNA subgroups. These clusters of distinct miRNAs were characterized by differences in expression levels that can significantly discriminate between the tumor types BC, OC and EC. However, no significant subtype-specific miRNA expression signature differences could be detected among the respective cancer types analyzed.

A parallel comparison of entity-specific clustering habits highlighted a BC-specific miRNA subpanel of six miRNAs that exhibited significantly different expression levels compared with those observed in EC and OC in vitro models. In particularly, members of the miR-30 family were identified in this respect.

Comparisons of miRNA expression signatures in either $\mathrm{BC} / \mathrm{OC}, \mathrm{BC} / \mathrm{EC}$ or EC/OC clearly revealed the most miRNA expression profile differences in the comparison of $\mathrm{BC}$ vs. OC, with ten of the 25 miRNAs exhibiting significantly different expression levels in these tumor types. Members of the miR-30 family were identified to be significantly differentially expressed, in addition to few more types, including miR-9, which has previously been described as a prognostic marker in OC (45), as well as miR-222 and miR-29a, which are known triggers in breast cancer therapy resistance mechanisms (46). In previous studies, the let-7 family has been reported to exhibit decreased expression levels in OC tissues as well as in OC cell lines, and has been identified to serve a role in OC progression $(47,48)$. In contrast to the literature, in the present study, let-7b was found to be upregulated in OC cells compared with BC cells.

A direct comparison of $\mathrm{EC}$ and $\mathrm{BC}$ miRNA expression signatures revealed six miRNAs with significantly different expression levels. Again, members of the miR-30 family were prominent, but also miR-15b and mi-200b were identified in this comparison. miR-15b has been described as an aberrantly regulated tumor suppressor (49), whereas miR-200b has a role in epithelial-mesenchymal transition processes (50).

The miRNAs miR-92a, miR-106b, miR-200b and miR-222 compose the smaller subgroup of four miRNAs that exhibited significant expression differences in EC compared with $\mathrm{OC}$ in vitro models. Consistent with a previous study by Záveský et al (51), the present data confirmed the differential expression of the miRNAs miR-92a, miR-106b and miR-200b in EC compared with OC. Upregulated expression levels of 
miR-222 in OC cells were found to associated with epithelial $\mathrm{OC}$ in a previous investigation (52).

In conclusion, the diagnostic power and validity of entity-specific miRNA clusters is partially limited due to individual cell type characteristics, such as receptor status or tumor origin (primary tumor or metastasis). For instance, in the present study the estrogen receptor (ER) EC cell line exhibited a different miRNA expression compared with two $\mathrm{ER}^{+} \mathrm{EC}$ cell lines. In addition, EFO-27 deviated from the other $\mathrm{OC}$ in vitro models to a certain extent, thus an intra-entity variation in miRNA expression signatures has to be taken into account. Furthermore, the present analyses revealed a notable difference in the molecular relationship of EC and OC compared with BC. Therefore, the number of miRNAs with distinguishing expression levels was markedly increased in EC and OC vs. BC than in the comparison between EC vs. $\mathrm{OC}$.

To pursue the identification of a clinically valuable highly entity-specific signature panel with diagnostic power for implementation in routine screening, the obtained data of the present discovery phase approach require further verification and validation. Thus, additional and extended in vitro analyses, followed by translational studies using patients' tissues and liquid biopsy materials should be performed in further analyses to provide substantial evidence for miRNA-based biomarker expression signatures that enable tumor detection, characterization and potential therapy monitoring.

\section{Acknowledgements}

Not applicable.

\section{Funding}

No funding was received.

\section{Availability of data and material}

The datasets used and/or analyzed during the current study are available from the corresponding author on reasonable request.

\section{Authors' contributions}

The project idea and experimental design was conceived by $\mathrm{MH}, \mathrm{MJ}, \mathrm{DW}, \mathrm{SM}, \mathrm{BK}$ and TE. In vitro experiments were performed by MJ, CN and DW. Data and statistical analyses were performed by GR, supported by DW, TE and MH. MH, IG, JW, TE, GR, MV, KB and JA interpreted the results and wrote the manuscript. GR, MV, BK, KB and SM critically revised the final version of the manuscript. All authors read and approved the final manuscript.

\section{Ethics approval and consent to participate}

Not applicable.

\section{Patient consent for publication}

Not applicable.

\section{Competing interests}

The authors declare that they have no competing interests.

\section{References}

1. Heywang-Koebrunner S, Bock K, Heindel W, Hecht G, Regitz-Jedermann L, Hacker A and Kaeaeb-Sanyal V: Mammography Screening-as of 2013. Geburtshilfe Frauenheilkd 73: 1007-1016, 2013.

2. Clarke MA, Long BJ, Del Mar Morillo A, Arbyn M, Bakkum-Gamez JN and Wentzensen N: Association of endometrial cancer risk with postmenopausal bleeding in Women: A systematic review and meta-analysis. JAMA Intern Med 178: 1210-1222, 2018

3. Steiner E, Eicher O, Sagemüller J, Schmidt M, Pilch H, Tanner B, Hengstler JG, Hofmann M and Knapstein PG: Multivariate independent prognostic factors in endometrial carcinoma: A clinicopathologic study in 181 patients: 10 years experience at the department of obstetrics and gynecology of the Mainz University. Int J Gynecol Cancer 13: 197-203, 2003.

4. Tejerizo-Garcia A, Jiménez-López JS, Muñoz-González JL, Bartolomé-Sotillos S, Marqueta-Marqués L, López-González G and Gómez JF: Overall survival and disease-free survival in endometrial cancer: Prognostic factors in 276 patients. Onco Targets Ther 9: 1305-1313, 2013.

5. Das PM and Bast RC Jr: Early detection of ovarian cancer. Biomark Med 2: 291-303, 2008.

6. Howlader N, Noone AM, Krapcho M, Miller D, Brest A, Yu M, Ruhl J, Tatalovich Z, Mariotto A, Lewis DR, Chen HS, Feuer EJ and Cronin KA (eds). SEER Cancer Statistics Review, 1975-2017, National Cancer Institute. Bethesda, MD, USA. https://seer. cancer.gov/csr/1975_2017/,

7. Frangogiannis NG: Biomarkers: Hopes and challenges in the path from discovery to clinical practice. Transl Res 159: 197-204, 2012.

8. Makarova JA, Shkurnikov MU, Wicklein D, Lange T, Samatov TR, Turchinovich AA and Tonevitsky AG: Intracellular and extracellular microRNA: An update on localization and biological role. Prog Histochem Cytochem 51: 33-49, 2016.

9. Hayes J, Peruzzi PP and Lawler S: MicroRNAs in cancer: Biomarkers, functions and therapy. Trends in Molecular Medicine 20: 460-469, 2014.

10. Croce CM: Causes and consequences of microRNA dysregulation in cancer. Nat Rev Genet 10: 704-714, 2009.

11. Kanekura K, Nishi H, Isaka K and Kuroda M: MicroRNA and gynecologic cancers. J Obstet Gynaecol Res 42: 612-617, 2016.

12. Kurozumi S, Yamaguchi Y, Kurosumi M, Ohira M, Matsumoto $H$ and Horiguchi J: Recent trends in microRNA research into breast cancer with particular focus on the associations between microRNAs and intrinsic subtypes. J Hum Genet 62: 15-24, 2016.

13. Nakamura K, Sawada K, Yoshimura A, Kinose Y, Nakatsuka E and Kimura T: Clinical relevance of circulating cell-free microRNAs in ovarian cancer. Mol Cancer 15: 48, 2016.

14. Rapisuwon S, Vietsch EE and Wellstein A: Circulating biomarkers to monitor cancer progression and treatment. Comput Struct Biotechnol J 14: 211-222, 2016.

15. Torres A, Torres K, Pesci A, Ceccaroni M, Paszkowski T, Cassandrini P, Zamboni G and Maciejewski R: Diagnostic and prognostic significance of miRNA signatures in tissues and plasma of endometrioid endometrial carcinoma patients. Int J Cancer 132: 1633-1645, 2013.

16. Widodo, Djati MS and Rifa'i M: Role of microRNAs in carcinogenesis that potential for biomarker of endometrial cancer. Ann Med Surg (Lond 7: 9-13, 2016.

17. Yanokura M, Banno K, Iida M, Irie H, Umene K, Masuda K, Kobayashi Y, Tominaga E and Aoki D: MicroRNAS in endometrial cancer: Recent advances and potential clinical applications. Excli J 14: 190-198, 2015.

18. Hirschfeld M, Rücker G, Weiß D, Berner K, Ritter A, Jäger M and Erbes T: Urinary exosomal MicroRNAs as potential non-invasive biomarkers in breast cancer detection. Mol Diagn Ther 24: 215-232, 2020.

19. Ritter A,HirschfeldM,BernerK,JaegerM,Grundner-CulemannF, Schlosser P, Asberger J, Weiss D, Noethling C, Mayer S and Erbes T: Discovery of potential serum and urine-based microRNA as minimally-invasive biomarkers for breast and gynecological cancer. Cancer Biomark 27: 225-242, 2020. 
20. Ritter A, Hirschfeld M, Berner K, Rücker G, Jäger M, Weiss D, Medl M, Nöthling C, Gassner S, Asberger J and Erbes T: Circulating noncoding RNA-biomarker potential in neoadjuvant chemotherapy of triple negative breast cancer? Int J Oncol 56: $47-68,2020$.

21. Lou Y, Yang X, Wang F, Cui Z and Huang Y: MicroRNA-21 promotes the cell proliferation, invasion and migration abilities in ovarian epithelial carcinomas through inhibiting the expression of PTEN protein. Int J Mol Med 26: 819-827, 2010.

22. Qin X, Yan L, Zhao X, Li C and Fu Y: MicroRNA-21 overexpression contributes to cell proliferation by targeting PTEN in endometrioid endometrial cancer. Oncol Lett 4: 1290-1296, 2012.

23. Frankel LB, Christoffersen NR, Jacobsen A, Lindow M, Krogh A and Lund AH: Programmed cell death 4 (PDCD4) is an important functional target of the microRNA miR-21 in breast cancer cells. J Biol Chem 283: 1026-1033, 2008.

24. Yan LX, Huang XF, Shao Q, Huang MY, Deng L, Wu QL, Zeng YX and Shao JY: MicroRNA miR-21 overexpression in human breast cancer is associated with advanced clinical stage, lymph node metastasis and patient poor prognosis. RNA 14 2348-2360, 2008.

25. Au Yeung CL, Co NN, Tsuruga T, Yeung TL, Kwan SY, Leung CS, Li Y, Lu ES, Kwan K, Wong KK, et al: Exosomal transfer of stroma-derived miR21 confers paclitaxel resistance in ovarian cancer cells through targeting APAF1. Nat Commun 7: 1150,2016

26. Greene SB, Herschkowitz JI and Rosen JM: Small players with big roles: microRNAs as targets to inhibit breast cancer progression. Curr Drug Targets 11: 1059-1073, 2010.

27. Encarnacion J, Ortiz C, Vergne R, Vargas W, Coppola D and Matta JL: High DRC Levels are associated with Let-7b overexpression in women with breast cancer. Int J Mol Sci 17: 865, 2016.

28. Chung YW, Bae HS, Song JY, Lee JK, Lee NW, Kim T and Lee KW: Detection of microRNA as novel biomarkers of epithelial ovarian cancer from the serum of ovarian cancer patients. Int J Gynecol Cancer 23: 673-679, 2013.

29. Tang Z, Ow GS, Thiery JP, Ivshina AV and Kuznetsov VA: Meta-analysis of transcriptome reveals let-7b as an unfavorable prognostic biomarker and predicts molecular and clinical subclasses in high-grade serous ovarian carcinoma. Int J Cancer 134: 306-318, 2014

30. Yu F, Yao H, Zhu P, Zhang X, Pan Q, Gong C, Huang Y, Hu X, Su F, Lieberman J and Song E: let-7 regulates self renewal and tumorigenicity of breast cancer cells. Cell 131: 1109-1123, 2007.

31. Cheng CW, Wang HW, Chang CW, Chu HW, Chen CY, Yu JC, Chao JI, Liu HF, Ding SL and Shen CY: MicroRNA-30a inhibits cell migration and invasion by downregulating vimentin expression and is a potential prognostic marker in breast cancer. Breast Cancer Res Treat 134: 1081-1093, 2012.

32. Rodriguez-Gonzalez FG, Sieuwerts AM, Smid M, Look MP, Meijer-van Gelder ME, de Weerd V, Sleijfer S, Martens JW and Foekens JA: MicroRNA-30c expression level is an independent predictor of clinical benefit of endocrine therapy in advanced estrogen receptor positive breast cancer. Breast Cancer Res Treat 127: 43-51, 2011

33. Bockhorn J, Dalton R, Nwachukwu C, Huang S, Prat A, Yee K, Chang YF, Huo D, Wen Y, Swanson KE, et al: MicroRNA-30c inhibits human breast tumour chemotherapy resistance by regulating TWF1 and IL-11. Nat Commun 4: 1393, 2013.

34. Lee H, Park CS, Deftereos G, Morihara J, Stern JE, Hawes SE, Swisher E, Kiviat NB and Feng Q: MicroRNA expression in ovarian carcinoma and its correlation with clinicopathological features. World J Surg Oncol 10: 174, 2012.

35. Cabarcas SM, Thomas S, Zhang X, Cherry JM, Sebastian T, Yerramilli S, Lader E, Farrar WL and Hurt EM: The role of upregulated miRNAs and the identification of novel mRNA targets in prostatospheres. Genomics 99: 108-117, 2012.

36. Wang Y, Li L, Qu Z, Li R, Bi T, Jiang J and Zhao H: The expression of miR-30a* and miR-30 $\mathrm{e}^{*}$ is associated with a dualistic model for grading ovarian papillary serious carcinoma. Int $\mathrm{J}$ Oncol 44: 1904-1914, 2014.

37. Shang C, Lu YM and Meng LR: MicroRNA-125b down-regulation mediates endometrial cancer invasion by targeting ERBB2. Med Sci Moni 18: BR149-BR155, 2012.

38. Li C, Gao Y, Zhang K, Chen J, Han S, Feng B, Wang R and Chen L: Multiple Roles of MicroRNA-100 in human cancer and its therapeutic potential. Cellular Physiology and Biochemistry 37: 2143-2159, 2015
39. Iorio MV, Ferracin M, Liu CG, Veronese A, Spizzo R, Sabbioni S, Magri E, Pedriali M, Fabbri M, Campiglio M, et al: MicroRNA gene expression deregulation in human breast cancer. Cancer research 65: 7065-7070, 2005.

40. Mattie MD, Benz CC, Bowers J, Sensinger K, Wong L, Scott GK, Fedele V, Ginzinger D, Getts R and Haqq C: Optimized high-throughput microRNA expression profiling provides novel biomarker assessment of clinical prostate and breast cancer biopsies. Mol Cancer 5: 24, 2006.

41. Guan Y, Yao H, Zheng Z, Qiu G and Sun K: miR-125b targets BCL3 and suppresses ovarian cancer proliferation. Int J Cancer 128: 2274-2283, 2011

42. Livak KJ and Schmittgen TD: Analysis of relative gene expression data using real-time quantitative PCR and the 2(-Delta Delta C(T)) method. Methods 25: 402-408, 2001.

43. Pfaffl MW, Tichopad A, Prgomet C and Neuvians TP: Determination of stable housekeeping genes, differentially regulated target genes and sample integrity: BestKeeper-Excel-based tool using pair-wise correlations. Biotechnol Lett 26: 509-515, 2004.

44. Wang H, Peng R, Wang J, Qin Z and Xue L: Circulating microRNAs as potential cancer biomarkers: The advantage and disadvantage. Clin Epigenetics 10: 59, 2018

45. Sun H, Shao Y, Huang J, Sun S, Liu Y, Zhou P and Yang H: Prognostic value of microRNA-9 in cancers: A systematic review and meta-analysis. Oncotarget 7: 67020-67032, 2016.

46. Zhong S, Li W, Chen Z, Xu J and Zhao J: miR-222 and miR-29a contribute to the drug-resistance of breast cancer cells. Gene 531: 8-14, 2013.

47. Dahiya N and Morin PJ: MicroRNAs in ovarian carcinomas. Endocr Relat Cancer 17: F77-F89, 2010

48. Dahiya N, Sherman-Baust CA, Wang TL, Davidson B, Shih IeM, Zhang Y, Wood W III, Becker KG and Morin PJ: MicroRNA expression and identification of putative miRNA targets in ovarian cancer. PLoS One 3: e2436, 2008.

49. Zhao C, Wang G, Zhu Y, Li X, Yan F, Zhang C, Huang X and Zhang Y: Aberrant regulation of miR-15b in human malignant tumors and its effects on the hallmarks of cancer. Tumour Biol 37: 177-183, 2016

50. Madhavan D, Peng C, Wallwiener M, Zucknick M, Nees J, Schott S, Rudolph A, Riethdorf S, Trumpp A, Pantel K, et al: Circulating miRNAs with prognostic value in metastatic breast cancer and for early detection of metastasis. Carcinogenesis 37: 461-470, 2016

51. Záveský L, Jandáková E, Turyna R, Langmeierová L, Weinberger V, Záveská Drábková L, Hůlková M, Hořínek A, Dušková D, Feyereisl J, et al: Evaluation of Cell-Free Urine microRNAs expression for the use in diagnosis of ovarian and endometrial cancers. A Pilot Study. Pathol Oncol Res 21: $1027-1035,2015$.

52. Sun C, Li N, Zhou B, Yang Z, Ding D, Weng D, Meng L, Wang S, Zhou J, Ma D and Chen G: miR-222 is upregulated in epithelial ovarian cancer and promotes cell proliferation by downregulating P27 ${ }^{\text {kipl }}$. Oncol Lett 6: 507-512, 2013.

53. Lin Z, Li JW, Wang Y, Chen T, Ren N, Yang L, Xu W, He H, Jiang Y, Chen X, et al: Abnormal miRNA-30e expression is associated with breast cancer progression. Clin Lab 62: 121-128, 2016.

54. Kim SJ, Shin JY, Lee KD, Bae YK, Sung KW, Nam SJ and Chun KH: MicroRNA let-7a suppresses breast cancer cell migration and invasion through downregulation of $\mathrm{C}-\mathrm{C}$ chemokine receptor type 7. Breast Cancer Res 14: 1-12, 2012.

55. Liu K, Zhang C, Li T, Ding Y, Tu T, Zhou F, Qi W, Chen H and Sun X: Let-7a inhibits growth and migration of breast cancer cells by targeting HM. Int J Oncol 46: 2526-2534, 2015.

56. Wang L, Zheng W, Zhang S, Chen X and Hornung D: Expression of monocyte chemotactic protein-1 in human endometrial cancer cells and the effect of treatment with tamoxifen or buserelin. J Int Med Res 34: 284-290, 2006.

57. Chun SM, Park HJ, Kim CH and Kim I: The Significance of MicroRNA Let-7b, miR-30c, and miR-200c Expression in Breast Cancers. J Pathol Transl Med 45: 354-360, 2011.

58. Liu P, Qi M, Ma C, Lao G, Liu Y, Liu Y and Liu Y: Let7a inhibits the growth of endometrial carcinoma cells by targeting Aurora-B. FEBS Lett 587: 2523-2529, 2013.

59. Bayani J, Kuzmanov U, Saraon P, Fung WA, Soosaipillai A, Squire JA and Diamandis EP: Copy number and expression alterations of miRNAs in the ovarian cancer cell line OVCAR-3: Impact on kallikrein 6 protein expression. Clin Chem 59: 296-305, 2013 
60. Dong P, Ihira K, Xiong Y, Watari H, Hanley SJ, Yamada T, Hosaka M, Kudo M, Yue J and Sakuragi N: Reactivation of epigenetically silenced miR-124 reverses the epithelial-to-mesenchymal transition and inhibits invasion in endometrial cancer cells via the direct repression of IQGAP1 expression. Oncotarget 7: 20260-20270, 2016.

61. Nam EJ, Yoon H, Kim SW, Kim H, Kim YT, Kim JH, Kim JW and Kim S: MicroRNA expression profiles in serous ovarian carcinoma. Clin Cancer Res 14: 2690-2695, 2008.

62. Boren T, Xiong Y, Hakam A, Wenham R, Apte S, Wei Z, Kamath S, Chen DT, Dressman H and Lancaster JM: MicroRNAs and their target messenger RNAs associated with endometrial carcinogenesis. Gynecol Oncol 110: 206-215, 2008.

63. Kowalewska M, Bakula-Zalewska E, Chechlinska M, Goryca K, Nasierowska-Guttmejer A, Danska-Bidzinska A and Bidzinski M: microRNAs in uterine sarcomas and mixed epithelial-mesenchymal uterine tumors: A preliminary report. Tumour Biol 34: 2153-2160, 2013.

64. Markou A, Zavridou M, Sourvinou I, Yousef G, Kounelis S, Malamos N, Georgoulias V and Lianidou E: Direct comparison of metastasis-related miRNAs expression levels in circulating tumor cells, corresponding plasma, and primary tumors of breast cancer patients. Clin Chem 62: 1002-1011, 2016.

65. Bertoli G, Cava C, Castiglioni I: MicroRNAs: New biomarkers for diagnosis, prognosis, therapy prediction and therapeutic tools for breast cancer. Theranostics 5: 1122-1143, 2015.

66. Echevarria-Vargas IM, Valiyeva $F$ and Vivas-Mejia PE: Upregulation of miR-21 in cisplatin resistant ovarian cancer via JNK-1/c-Jun pathway. PLoS One 9: e97094, 2014.

67. Myatt SS, Wang J, Monteiro LJ, Christian M, Ho KK, Fusi L, Dina RE, Brosens JJ, Ghaem-Maghami S and Lam EW: Definition of microRNAs that repress expression of the tumor suppressor gene FOXO1 in endometrial cancer. 70: 367-377, 2010.

68. Ouzounova M, Vuong T, Ancey PB, Ferrand M, Durand G, Le-Calvez Kelm F, Croce C, Matar C, Herceg Z and Hernandez-Vargas H: MicroRNA miR-30 family regulates non-attachment growth of breast cancer cells. BMC Genomics 14: 139,2013

69. Chang CW, Yu JC, Hsieh YH, Yao CC, Chao JI, Chen PM, Hsieh HY, Hsiung CN, Chu HW, Shen CY and Cheng CW: MicroRNA-30a increases tight junction protein expression to suppress the epithelial-mesenchymal transition and metastasis by targeting Slug in breast cancer. Oncotarget 7: 16462-16478, 2016.

70. Berber U, Yilmaz I, Narli G, Haholu A, Kucukodaci Z and Demirel D: miR-205 and miR-200c: Predictive Micro RNAs for lymph node metastasis in triple negative breast cancer. J Breast Cancer 17: 143-148, 2014.

71. Tsukamoto O, Miura K, Mishima H, Abe S, Kaneuchi M, Higashijima A, Miura S, Kinoshita A, Yoshiura K and Masuzaki H: Identification of endometrioid endometrial carcinoma-associated microRNAs in tissue and plasma. Gynecol Oncol 132: 715-721, 2014.

72. Nagaraja AK, Creighton CJ, Yu Z, Zhu H, Gunaratne PH, Reid JG, Olokpa E, Itamochi H, Ueno NT, Hawkins SM, et al: A link between mir-100 and FRAP1/mTOR in clear cell ovarian cancer. Mol Endocrinol 24: 447-463, 2010.

73. Calura E, Fruscio R, Paracchini L, Bignotti E, Ravaggi A, Martini P, Sales G, Beltrame L, Clivio L, Ceppi L, et al: MiRNA landscape in stage I epithelial ovarian cancer defines the histotype specificities. Clin Cancer Res 19: 4114-4123, 2013.

74. Zhou J, Gong G, Tan H, Dai F, Zhu X, Chen Y, Wang J, Liu Y, Chen P, Wu X and Wen J: Urinary microRNA-30a-5p is a potential biomarker for ovarian serous adenocarcinoma. Oncol Rep 33: 2915-2923, 2015.

75. Ayaz L, Çayan F, Balci Ş, Görür A, Akbayir S, Yıldırım Yaroğlu H, Doğruer Unal N and Tamer L: Circulating microRNA expression profiles in ovarian cancer. J Obstet Gynaecol 34: 620-624, 2014.

76. Hausler SF, Keller A, Chandran PA, Ziegler K, Zipp K, Heuer S, Krockenberger M, Engel JB, Hönig A, Scheffler M, et al: Whole blood-derived miRNA profiles as potential new tools for ovarian cancer screening. Br J Cancer 103: 693-700, 2010.

77. Shukla K, Sharma AK, Ward A, Will R, Hielscher T, Balwierz A, Breunig C, Münstermann E, König R, Keklikoglou I and Wiemann S: MicroRNA-30c-2-3p negatively regulates NF- $\kappa B$ signaling and cell cycle progression through downregulation of TRADD and CCNE1 in breast cancer. Mol Oncol 9: 1106-1119, 2015.
78. Tanic M, Yanowsky K, Rodriguez-Antona C, Andrés R, Márquez-Rodas I, Osorio A, Benitez J and Martinez-Delgado B: Deregulated miRNAs in hereditary breast cancer revealed a role for miR-30c in regulating KRAS oncogene. PLoS One 7: e38847, 2012.

79. Sorrentino A, Liu CG, Addario A, Peschle C, Scambia G and Ferlini C: Role of microRNAs in drug-resistant ovarian cancer cells. Gynecol Oncol 111: 478-486, 2008.

80. Gong Y, He T, Yang L, Yang G, Chen Y and Zhang X: The role of miR-100 in regulating apoptosis of breast cancer cells. Sci Rep 5: 11650, 2015.

81. Zaman MS, Maher DM, Khan S, Jaggi M and Chauhan SC: Current status and implications of microRNAs in ovarian cancer diagnosis and therapy. J Ovarian Res 5: 44, 2012.

82. Okuda H, Xing F, Pandey PR, Sharma S, Watabe M, Pai SK, Mo YY, Iiizumi-Gairani M, Hirota S, Liu Y, et al: miR-7 suppresses brain metastasis of breast cancer stem-like cells by modulating KLF4. Cancer Res 73: 1434-1444, 2013.

83. Banno K, Yanokura M, Iida M, Adachi M, Nakamura K, Nogami Y, Umene K, Masuda K, Kisu I, Nomura H, et al: Application of microRNA in diagnosis and treatment of ovarian cancer. Biomed Res Int 2014: 232817, 2014.

84. Ramon LA, Braza-Boïls A, Gilabert J, Chirivella M, España F, Estellés A and Gilabert-Estellés J: microRNAs related to angiogenesis are dysregulated in endometrioid endometrial cancer. Hum Reprod 27: 3036-3045, 2012.

85. Kinose Y, Sawada K, Nakamura K and Kimura T: The Role of MicroRNAs in Ovarian Cancer. Biomed Res Int 2014: 11, 2014.

86. Lu J, Zhang X, Zhang R and Ge Q: MicroRNA heterogeneity in endometrial cancer cell lines revealed by deep sequencing. Oncol Lett 10: 3457-3465, 2015.

87. Wu Q, Guo L, Jiang F, Li L, Li Z and Chen F: Analysis of the miRNA-mRNA-lncRNA networks in ER+ and ER- breast cancer cell lines. J Cell Mol Med 19: 2874-2887, 2015.

88. Chong GO, Jeon HS, Han HS, Son JW, Lee YH, Hong DG, Lee YS and Cho YL: Differential MicroRNA Expression Profiles in Primary and Recurrent Epithelial Ovarian Cancer. Anticancer Res 35: 2611-2617, 2015.

89. Singh SR and Rameshwar P (eds): MicroRNA in development and in the progression of cancer. Springer-Verlag New York, 2014.

90. Brockhoff G, Heckel B, Schmidt-Bruecken E, Plander M, Hofstaedter F, Vollmann A and Diermeier S: Differential impact of Cetuximab, Pertuzumab and Trastuzumab on BT474 and SK-BR-3 breast cancer cell proliferation. Cell Prolif 40: 488-507, 2007.

91. Lasfargues EY, Coutinho WG and Redfield ES: Isolation of two human tumor epithelial cell lines from solid breast carcinomas. J Natl Cancer Inst 61: 967-978, 1978.

92. Subik K, Lee JF, Baxter L, Strzepek T, Costello D, Crowley P, Xing L, Hung MC, Bonfiglio T, Hicks DG and Tang P: The Expression Patterns of ER, PR, HER2, CK5/6, EGFR, Ki-67 and AR by immunohistochemical analysis in breast cancer cell lines. Breast Cancer 4: 35-41, 2010.

93. Lee S, Yang W, Lan KH, Sellappan S, Klos K, Hortobagyi G, Hung MC and Yu D: Enhanced sensitization to taxol-induced apoptosis by herceptin pretreatment in ErbB2-overexpressing breast cancer cells. Cancer Res 62: 5703-5710, 2002.

94. Kim DJ, Lee WY, Park NW, Kim GS, Lee KM, Kim J, Choi MK Lee GH, Han W and Lee SK: Drug response of captured BT20 cells and evaluation of circulating tumor cells on a silicon nanowire platform. Biosens Bioelectron 67: 370-378, 2015.

95. Kloten V, Schlensog M, Eschenbruch J, Gasthaus J, Tiedemann J, Mijnes J, Heide T, Braunschweig T, Knüchel R and Dahl E: Abundant NDRG2 expression is associated with aggressiveness and unfavorable patients' outcome in basal-like breast cancer. PLoS One 11: e0159073, 2016.

96. Croxtall JD, Elder MG and White JO: Hormonal control of proliferation in the Ishikawa endometrial adenocarcinoma cell line. J Steroid Biochem 35: 665-669, 1990.

97. Nishida M, Kasahara K, Kaneko M, Iwasaki H and Hayashi K: Establishment of a new human endometrial adenocarcinoma cell line, Ishikawa cells, containing estrogen and progesterone receptors. Nihon Sanka Fujinka Gakkai zasshi 37: 1103-1111, 1985 (In Japanese).

98. Dawe CJ, Banfield WG, Morgan WD, Slatick MS and Curth HO: Growth in continuous culture, and in hamsters, of cells from a neoplasm associated with acanthosis nigricans. J Natl Cancer Inst 33: 441-456, 1964. 
99. Korch C, Spillman MA, Jackson TA, Jacobsen BM, Murphy SK, Lessey BA, Jordan VC and Bradford AP: DNA profiling analysis of endometrial and ovarian cell lines reveals misidentification, redundancy and contamination. Gynecol Oncol 127: 241-248, 2012.

100. Basu M, Mukhopadhyay S, Chatterjee U and Roy SS: FGF16 promotes invasive behavior of SKOV-3 ovarian cancer cells through activation of mitogen-activated protein kinase (MAPK) signaling pathway. J Biol Chem 289: 1415-1428, 2014.

101. Irmer G, Bürger C, Müller R, Ortmann O, Peter U, Kakar SS Neill JD, Schulz KD and Emons G: Expression of the messenger RNAs for luteinizing hormone-releasing hormone (LHRH) and its receptor in human ovarian epithelial carcinoma. Cancer Res 55: 817-822, 1995.
102. Yoon J, Kim ES, Lee SJ, Park CW, Cha HJ, Hong BH and Choi KY: Apoptosis-related mRNA expression profiles of ovarian cancer cell lines following cisplatin treatment. J Gynecol Oncol 21: 255-261, 2010

103. Langdon SP and Lawrie SS: Establishment of ovarian cancer cell lines. Methods Mol Med 39: 155-159, 2001.

104. Shukla J, Sharma U, Kar R, Varma IK, Juyal S, Jagannathan NR and Bandopadhyaya GP: Tamoxifen-2-hydroxylpropylbeta-cyclodextrin-aggregated nanoassembly for nonbreast estrogen-receptor-positive cancer therapy. Nanomedicine (Lond) 4: 895-902, 2009. 